\title{
Representation of Women and Circulation of Power in Khaled Hosseini's and the Mountains Echoed: A Montrosean Reading
}

\author{
Ghulam Yahya Asghari1 ${ }^{1, *}$, Rahimullah Ramish², Ali Akbar Zawuli ${ }^{3}$ \\ ${ }^{* 1}$ Assistant Professor and Head of English Department, Faculty of Languages \& Literature, Ghazni University, Afghanistan
${ }^{2}$ Assistan Professor and Dean of Languages \& Literature Faculty, Ghazni University, Afghanistan
${ }^{3}$ Assistant Professor and Head of Persian Department, Faculty of Languages \& Literature, Ghazni University, Afghanistan
}

Received: 29 Nov 2021; Received in revised form: 20 Dec 2021; Accepted: 25 Dec 2021; Available online: 31 Dec 2021 C2021 The Author(s). Published by Infogain Publication. This is an open access article under the CC BY license (https://creativecommons.org/licenses/by/4.0/).

\begin{abstract}
This paper is an intertextual analysis of Khaled Hosseini's And the Mountains Echoed under the light of Louis Adrian Montrose's theory of power relation. Montrose asserts on textuality of history and historicity of text. By textuality of history, he refers to the functionality and constructedness of history, while historicity of texts refers to cultural specificity and social embodiments of all modes of writing, the rootedness of a texts in the social, historical, political and cultural ambiance of its production. He believes that there is no such a thing as objective history because history is a narrative, which, like language is produced in a context and governed by social, economic and political groups or institutions. Hence, Montrose in an intertextual analysis of Shakespeare's A Midsummer Night's Dream applied his theory of power relation to figure out the manipulated and symbolic power of women during Elizabeth in Renaissance period. Therefore, this paper aims to intertextually analyze the situation of female characters in Hosseini's And the Mountains Echoed based on power relationin order to discover how Khaled Hosseini represented the social, political, and economic condition of Afghan womenin the $20^{\text {th }}$ century in Afghan society.
\end{abstract}

Keywords - Intertextuality, Institution, Khaled Hosseini, Louis Adrian Montrose, Power, Women.

\section{INTRODUCTION}

In the roughly a hundred or a hundred and ten years, several governments have ruled in Afghanistan and Afghan people have experienced different regimes. Since power plays a key role in changing a regime and continuing another one, social, political, economic and educational life of people was highly influenced under such conditions. Women as half of the society have been the sole victims of power structure of family, society and government in the $20^{\text {th }}$ century in Afghanistan. Men as power runners in the country, especially in the government and commonly in the families have been in the highest position, and women were controlled by them. The discourse that majority of Afghan writers in Afghanistan and out of this country have paid a very close attention to, was the matter of women in Afghan society in the $20^{\text {th }}$ century and the beginning of the $21^{\text {st }}$ century. In this paper, we are going to discuss the predicament of female characters in And the Mountains Echoed by Khaled Hosseini which narrates the life condition of Nila and Pari.

Khaled Hosseini as a contemporary author is a famous Afghan-American author who grew up with loving the treasures of classical Persian poetry. Hosseini writes beautifully and is a natural storyteller who writes in English. He has three best-selling novels which are The Kite Runner,A Thousand Splendid Suns and And the Mountains Echoed. Recently, he published a new novel See Prayer, but the subject matter of this novel is not Afghans and Afghanistan. 
The above-mentioned novels of Khaled Hosseini, generally, give the insight of the social injustice, war, patriarchy, power structures and women situation in Afghanistan for several decades. His first novel, The Kite Runner, depicts the story of the relationship between fathers and their sons and the role of heritage in shaping one's life. A Thousand Splendid Suns, Hosseini's second novel, tells the story of the soul-stirring connection between two oppressed Afghan women, Mariam and Laila. And the third one, And the Mountains Echoed represents the relationship between the ten-year old Abdullah and his three- year old sister, Pari, and their father's decision to sell her to a childless couple in Kabul. In addition, it tells the condition of Nila's life an event that ties various natives together.

In this paper, using intertextual method of analyzing, the researchers examine the predicament of Afghan women in And the Mountains Echoed based on power relation and the structures of power in order to figure out the factual figure and situation of Afghan women in the $20^{\text {th }}$ century. There are characters living abroad in this novel, but the focus of the researchers is to target only the female characters who live in Afghan society in the $20^{\text {th }}$ century in the novel. In intertextual analysis of Hosseini's And the Mountains Echoed, the researchers analyses some of the female characters' situation from the two other Afghan novels Noqra, Daughter of Kabul River by Homeira Qaderi and Our Alley by Akram Usman as Louis Montrose did in his paper Shaping Fantasies. The researchers' main concentration is on Hosseini's female characters' situation in And the Mountains Echoed.It should not be mistaken that this study is a New Historicism study not a feminism study because in feminism everything has a gender-based-relation, but in New Historicism everything happens has a power-basedrelation.

\section{LITERATURE REVIEW}

In this paper, the researchers summarize some of the relevant literature to prove the originality of this study. By this literature review, the researchers hope that the reader can understand the differentiation of this study with the other researches relevant to Khaled Hosseini's And the Mountains Echoed. This study varies from that of other critics who have written on various aspects of Khaled Hosseini's And the Mountains Echoed. Any reader of Hosseini's works will want to be conscious of the following noteworthy studies about Hosseini's And the Mountains Echoed in order to understand what gap has been left out which will be filled in this paper. In"Postcolonial Feministic Study of Khaled Hosseini's
And the Mountains Echoed",Prof. Dr. Kranti Vats and Imtiyaz Ahmad Tantrayanalyzed the life of Afghan women from a postcolonial feministic point of view. They believed that women encountered many difficulties in their lives because they were viewed as the weaker gender by men in the novel. As a result of such view toward women, they (women) were lead to depression because they felt themselves not equal to men. In addition, they felt inferior in comparison tomen. Therefore, women were represented through gender roles inAfghan society in comparison to men (Vats \& Tantray, 2019).Prathibha. P in herpaper, "There is only one, only one skill a woman like you and me needs in life... And it's this: tahamul. Endure": A Feminist Analysis of the Female Characters in Khaled Hosseini's And the Mountains Echoed and A ThousandSplendid Suns, discussed the character of Nila Wahdati from a view point of Feminism. She considered Nila as an intelligent woman and a rebellious character. Prathibha. P believed that Hosseini has portrayed Nila as a woman who wears "tradition-defying clothes" who did not care what people around her thought of her. She refused so many other things that her father brought on her and this showedrebellion as a feminist woman who fought for her freedom. Furthermore, when her father tried to beat her, this action even madeher more and more rebellious (Prathibha,2020). In addition to this, Rajkumari. C talkedabout diversity of love in his paper "Representation of Love in Khaled Hosseini's And the Mountains Echoed". He believed that love was not only taken in the romantic sense, but it could be seen between two persons such as love between a father and a son, a brother and sister or between friends. He described that Hosseini has beautifully depicted a brother and sister love in this novel. A brother who devoted to his sister and fate separated them and then reunited. The love between Abdullah and Pari, brother and sister in this novel represented the power of love which bonded two souls together (Rajkumari,2019).Beside this, Afghan society was a patriarchal, repressive, and oppressive and giving privileges to men based on Rhudhra's paper. The paper represented the harsh treatment of men toward women and justified under the name of culture, traditions and religion. Men were thought as individuals whereas women were considered as salable commodities which divides them into classes of men and women. A women's body was exposed to scrutiny, at home by father and brother, and outside by stranger (Rhudhra, 2016).

By considering the above reviews of literatures, current study analyzes Hosseini's And the Mountains under the lens of Louis Adriana Montrose's theory ofpower relation and the structure of powerin order to discover the predicament of female charactersto depict 
how these female characters demonstrate the actual situation of Afghan women in the $20^{\text {th }}$ century in Afghanistan. Contextualizing these novels and Montrosean intertextual reading, based on power relation,is a gap that no one has paid attention to that up to now. Hence, this research is totally different from the other previous studiesand fills the above mentioned gap.

\section{THEORY}

Louis Adrian Montrose's essay, Shaping Fantasies, appeared in the second issue of Representations, a collection of essays by Stephen Greenblatt. The subject of this essay by Montrose "Shaping Fantasies" is the construction of a powerful mythical identity for Elizabeth I. Such an identity portrayed through narratives and dramas which played out the "Shaping Fantasies" of Elizabethan culture. Mainly, Montrose's examination is based on two texts. The first one is a dream narrated in the autobiography of Simon Forman, and the second one is Shakespeare's A Midsummer Night's Dream (Greenblatt,1998).

Montrose's notion of the relationship between power and subversion may be different in "Shaping Fantasies". It is described that Elizabeth was unsteadily placed as a woman at the head of a patriarchal society which was very strong. It is also added that Elizabeth's power was then a series of contradictions and complications which had to be manipulated and managed, both on a "bureaucratically" and a symbolical level, in order to secure her interests as a flawless head of state. It is notable, of course, that the only possibility of subversion mentioned in the essay is one raised in Simon Forman's dream, itself suggestive of effective containment (Brannigan, 1998).

Louis Montrose in his essay professing the Renaissance: The Poetics and Politics of Culture argued that the key concern of new historicist critics was "the historicity of texts and the textuality of history". While "historicity of texts" refers to the "cultural specificity and social embedment of all mode of writing", the rootedness of a text in the social-historical, political and cultural ambiance of its production, He explained that by "the historicity of texts", all texts were embedded in specific social and cultural contexts. According to him, "textuality of history" refers to the functionality and constructedness of history. By "textuality of history", he meant that all of our knowledge and understanding of the past could only exist through the "surviving textual traces of the society in question", the very survival of which suggested that they were subject to "complex and subtle social processes of preservation and effacement".Montrose in his
essay"Professing the Renaissance: The Poetics and Politics of Culture" in Veeser's The New Historicism, argues a similar point as his fellow scholars do when it comes to the "synchronic" relationship between text and reality: a text is not simply the work of one author, it is a socially produced product that both gives shape to culture, as well as being given shape by that same culture it has an effect on (Vesser, 1989).

\section{METHODOLOGY}

Intertextuality is "a term denoting that any given text's meaning or interpretation is related or interrelated to the meaning of all other texts. Hence, no text can be interpreted in isolation, and all texts are intertextual"(Bressler, 2011).In an intertextual study, forinstance, Montrose analyzed Shakespeare's play, A Midsummer Night's Dream, by using intertextual method. Hence, Montrose gives an explanation of "intertextual study". He says, "My intertextual study of Shakespeare's A Midsummer Night's Dream and symbolic forms shaped by other Elizabethan lunatics, lovers, and poets construes the play as calling attention to itself, not only as an end but also as a source of cultural production." Thus, in writing of "Shaping Fantasies: Figurations of Gender and Power in Elizabethan Culture", he meant to propose the dialectical character of cultural representations: the fantasies by which the text of A Midsummer Night's Dream has been shaped are also those to which it gives shape. He adds that "I explore this dialectic within a specifically Elizabethan context of cultural production: the interplay between representations of gender and power in a stratified society in which authority is everywhere invested in meneverywhere, that is, except at the top" (Greenblatt, 1988).Beside A Midsummer Night's Dream and the autobiography of Simon Forman,Montrose also looks at some travel tales like a colonial travel narrative by Sir Walter Raleigh and other tales of the Amazon. So, here are widely diverse texts which have a common function in Montrose's analysis. These texts are to explain how the persona of Elizabeth I was invented and disseminated. It is also evident in this essay that literary texts and other texts are interdependent, and that they are not only produced by social and political discourse, but are also, in fact, the makers of this discourse, as Montrose sees A Midsummer Night's Dream, for example, playing a vital role in shaping the cult of Elizabeth I (Wolfreys, 2001).

To interpret the data, the researchers in this paper are going apply intertextuality method. By this method, the researchers use quotations from Hosseini's novel And the Mountains Echoed to interpret and analyze the situation of female characters of structure of power in Afghan families, 
society and government. In addition, they refer to Noqra, Daughter of Kabul River by Homeira Qaderi and Our Alleyby Dr. Akram Usman, the two other contemporary novels, to portray the situation of female characters. The purpose of such analysis is to discover the situation of Afghan women under several governmentsin the $20^{\text {th }}$ century in Afghanistan.

\section{FINDINGS}

Hosseini's novel And the Mountains Echoed describes the boundless miseries of Afghan women who were imprisoned in the power structure of men and institutions of power such as family, society and the government. They were always treated as the one who must always obey the men of their families and were not considered equal as men. Since Afghan society is patriarchal, repressive and oppressive and giving privileges to men, the harsh treatment toward women was justified in the name of cultural traditions and religion. Indeed, all these harshness and oppressions toward women rooted in the power that women were controlled through it by families, societies and the government. Men were born with respect, dignity and worth, whereas women were considered as salable items and powerless creatures. Men were considered as individuals highly powerful and controller, but women as bodies controlled by men of the families or society. Therefore, in her life, a woman's body was subjected to scrutiny to males at home by father and brothers, and outside by strangers which all rooted in power relationship and the dominant power structure in Afghanistan.

In Hosseini's novel And the Mountains Echoed, Nilaafter leaving Afghanistan and went to Paris was interviewed as a female poet by Etienne Boustouler. During the interview, the interviewer asked Nila to tell about her early life. Nila began her talks with showing an old wrinkled black-and-white photograph. In that photo, there was her father. The interviewer commented that his father looked quite distinguished in the photograph. Relevant to interviewer's comment, Nila told about her father that "he was part of the Pashtun aristocracy in Kabul. Highly educated, unimpeachable manner, appropriately sociable. A great raconteur too. At least in public" (Hosseini, 2013). Khaled Hosseini in this quote was going to portray Nila's father as an educated man, sociable and blameless man, but what we can infer from the last phrase that he has been so only in public life not in his domestic life. His domestic and private life seemed opposite to his public one. The interviewer asked Nila about the private life of her father, and Nila in response said that it was venture to guess. Nila's parents divorced and Nila had to stay with her father for the rest of her life. Nila stated:

My parents divorced in 1939 when I was ten. Letting me go with her was out of the question. So I stayed, and she left for Paris to live with her sister, Agnes. My father tried to mitigate the loss for me by occupying me with a private tutor and riding lessons and art lessons. But nothing replaces a mother (ibid.).

Hosseini's description of Nila's attitude seemedthat she wanted to be free and made up her mind by herself whether to stay with her father or leave along withher mother for France, but it was her father who determined and controlled the situation after Nila chose to stay with her father. Khaled Hosseini is going to give us the image of Afghan men and women through both of his characters Nila's father and Nila herself in order to show how men were at the top of the authority in the power structure ofAfghan families in the first half of the twentieth century in Afghanistan. Nila was occupied by her father to stay home and hired a private tutor. Nila was limited to go out to see strangers. So, here we can infer the "relation of power" which Montrose discusses. The word "occupying" in the above quote is quite clear that Nila was not independent and her father forced her to accept what he said. Nila's father was entertaining her by private tutor and riding lessons and so on in order to keep Nila at home and thatwas exactly what Montrose and other new historicists share in common that power is ruling through different institutions, Power was ruling in Nila's family through her father as the head of family. In fact, all decisions were made by Nila's father in relation to her life. Nila did not get along with his father during her childhood. Nila stated:

There were strains between us. We were quarreling. Quite a lot, which was a novelty for him. He wasn't accustomed to being talked back to, certainly not by women. We had rows over what I wore, where I went, what I said, how I said it, who I said it to (ibid.).

In the above excerpt, Khaled Hosseini tried to represent the image of an Afghan woman through the character of Nila and the image of and Afghan man through the character of Nila's father. It is inferred that Afghan men limited the domain of Afghan women and their freedom in the patriarchal society of Afghanistan. It is also inferred that there had been quite oppositions between Afghan men and women. Men of the families were dominants and at the top of the position in the families who were ordering and wanted women to obey. Ordering and obedience between these two characters portrayed the relationship of power of Afghanistan. Power 
interacted between them. Again, order, obey, lack of freedom and being the dominant one has shown the relation of power between the characters in the novel. Such power relation is Montrose's concern that women were ruled the structure of power placed men at the top. That is power which is ruling through institutions. Hence, it is discovered that families and other institutions were the source of ruling on women in Afghan society.The more the interview goes on in the novel, the more other sides of Nila Wahdati's life are revealed and it seems that whatever she wanted to or accomplish, faced with the opposition of her father. Nila Wahdati continued:

And then I took to falling in love. Often, desperately, and, to my father's horror, with the wrong sort. A housekeeper's son once, another time a low-level civil servant who handled some business affairs for my father. Foolhardy, wayward passions, all of them doomed from the start. I arranged clandestine rendezvous and slipped away from home, and, of course, someone would inform my father that I'd been spotted on the streets somewhere. They would tell him that I was cavorting - they always put it like that-I was "cavorting." Or else they would say I was "parading" myself. My father would lock me up. For days. He would say from the other side of the door, you humiliate me. Why do you humiliate me so? What will I do about you? And sometimes he answered the question with his belt, or a closed fist. He chased me around the room. I suppose he thought he could terrorize me into submission (ibid).

Khaled Hosseini is going to represent hardship and imprisonment of Afghan women through the above quote from the novel. He wants to show that his character Nila was not independent, but surrounded through the wills of her father in every aspect of her life. In fact, Hosseini indicates to an Afghan woman through Nila who had not been self-determining. It is inferred that Afghan women had no choice and no voice because men did not want them to do what they wanted. Nila's father obviously brought her under his own control. She had no right to love someone, or to walk away home with her beloved or even go outside the house even for walking. Her father, indeed, marginalized Nila and kept her out of the sight of people. He thought that women who go out humiliates men of the family. So, Khaled Hosseini is going to exemplify that Afghan women were not allowed to go outside the house because of the men's thought of humiliation. Hosseini also represented that Afghan women had not had a good condition of life because men of the families imprisoned them in the house and tortured them. It seems that Afghan women's passions and feelings were suppressed by their families especially men because they could not even love someone or to go out with one they loved.Hence, the condition of Nila's life in such a family had a direct connection with power which Louis Adrian Montrose speaks of it. Her father as a ruler and especially as the family head, was ruling in his family and forcing Nila to do what seemed appropriate to him. Therefore, it is inferred that Afghan men wereon power based on a manmade structure of power in the Afghan families and Afghan women were controlled by them.

Before going to Paris,Nila was living in Kabul. She adopted Pari, daughter of Saboor and sister of Abdullah. Since Pari's father was a simple worker, Uncle Nabi, Nila's driver and chauffeur found Saboor a job in Nila's mansion. Nila, after marriage to Mr. Suleiman could not give birth to a child and this couple had no child in their married life. After her marriage with Suleiman, Nila was childless and when she saw Pari, she admired her with beautiful words. It seemedthat Nilawas in search of such a baby to adopt as her own daughter. Nila demanded UncleNabi, the chauffeur, to find her a daughter to adopt. That was Uncle Nabi who arranged the deal of selling and buying Pari. What made more to think in this scene was that Khaled Hosseini, unfortunately, has not given more insight into the mind of Saboor, but he has told the reader a great deal about Nabi, Pari's Uncle, including his motivation. So, Pari was sold to Nila. If we come to Pari, she as a girlwas sold by her father, Saboor. Selling her to Nila, was only on the hand of her father. Khaled Hosseini tried to exemplify the value of women in Afghan society where women were sold in exchange of money. To connect this point to Louis Adrian Montrose's power relation and power rules through its institutions, Khaled Hosseini exemplifies Saboor's family and Saboor himself at the top of authority in his family who ruled and made the decision about the life of his child, Pari. Hosseini portrayed a picture of Afghan families through Saboor where the structure of power was that men should be at the top. Here is that powerwas ruling through Saboor and his family regarding Pari's life.

Hosseini's magical style forces the readers to read every single page of the novel in order to understand the predicament of the female characters reeling under the burden of stereotyped man ruling society. Saboor sold her daughter, Pari, to Nila and the scene while he was selling Pari, was indeed touching and heart tearing moment which Khaled Hosseini has created a feeling of empathy in his readers. Selling of his beautiful daughter, Pari, to a rich woman of Kabul symbolized the traditional and oppressive mind set of Afghans who believed that women were less important than men in Afghan society where men were 
powerful enough to do what they wanted to women either to sell or not. Poverty of Saboor compelled him to sell his daughter, but what made the reader to think of uselessness of women in Afghan society than men was that Saboor had a son as well. He never forced his son even to help him in that hard condition. It is inferred that Afghan women were sacrificed due to the intensions of their families whether to be sold or not. When Saboor sold his daughter, Pari, the mountains echoed his sin. Hosseini has given the image of the echoing of the mountains in order to represent the brutality of an Afghan man who sold his pretty daughter in exchange of money because of power which had at hand. Such brutality and selling was because men in paternal families wereconsidered dominant and they made any judgment and decision about the women in their families. Any kind of relationship in such a structure of powerwas based on a power relation between men and women, the power that Louis Adrian Montrose and other new historicist stressed on it.

There is an interrelationship between Hosseini's And the Mountains Echoed and Homeira Qaderi's novel, Noqra, Daughter of Kabul Riverwhichhas narrated the story of seven Afghan women who were working in the government palace of Afghanistan due to the need and force in order to spend their life. In both novel, we saw that female characters had the same fate. Because of man dominant structure of power in families and government, women were bearing so many difficulties in their lives. Noqra, the main character of the novel, came to the palace in order to work because her father was old and unable to support the family economically. There, Noqra fell in love with a soldier named Ezmarai. She became pregnant with his child. After a short while, Ezmarai left Kabul to Ghazni for a mission. He promised Noqra for returning, but never returned to Kabul. Noqra gavebirth to a daughter. Her name was Aqlima. Noqra's hidden love with Ezmarai wasagainst thefamily and social norms in Afghan society. So, she was rejected by her family and was not allowed to live with her parents. She had to live her whole life far away from her family. The narrator of the story was Aqlima, the illegitimate daughter of Noqra and Ezmarai. In addition to Aqlima, other characters were also narrating Noqra's life to the main narrator, Aqlima.

Similar to the female characters of Khaled Hosseini's And the Mountains Echoed, the female characters in Noqra Daughter of Kabul River, also exemplify the situation of the Afghan women form different parts of Afghanistan who spend a life full of hardship in Afghan society where power lied in the hands of men and the institutions of power. Men, however, were not more on the scene, but their power was sensible everywhere. For example, the women had to serve the men in the palace and women were away from other social and political positions because men had to run those positions. Here, we see that Montrose's "power relation" matches in the life conditions of these characters in the novel. Noqra, when in such a society became pregnant, her father forced her to leave the house and she was rejected by her father and family. Through Noqra, Homeira Qaderi tried to show the image of a family of Afghans whose daughter was rejected because of pregnancy from her beloved which was against the norms and traditions of Afghan society. Fathers and brothers were the only rulers and dominant people in families of Afghan paternal society. Therefore, based on Montrose's "power relation", Noqra's family as an institution of power was the only power ruler in her life and denied her. The structure of power was in a way that family specially father could make the decision about the life of women.

Forced marriage is still one of the common issues in Afghan society that Homeira Qaderi also exemplified in her novel as Khaled Hosseini did too. So, Qaderi demonstrated in her novel to the life of her female character, Zarimah's mother,in order to give a picture of Afghan women's forced marriage tradition. In the novel, Zarimah's uncle committed cruelty and oppression against Zarimah's her mother. After her father died, her uncle forced her mother to marry him. Zarimah said "My Uncle took me in his room and there told to my mother in front of all: Either marry me, or leave the house without Zarimah"(Qaderi, 2015). Through this quotation Qaderi portrayed her female character as oppressed and the one who was controlled, limited, and forced to a compulsory marriage by her father-in-law's family. In fact, it is inferred that women suffered and forced to compulsory marriages in the first half of the twentieth century in Afghan society where men were deciding about the marriage of women. It is the point that Montrose indicates that power is ruling everywhere and lies in the hands of men and institutions of power. Here, a man as the head of family and family as an institution of power forced Zarimah's mother to accept a forced marriage. Similar to Khaled Hosseini's novel, we saw that the structure of power was family based, and the family (father) had the only right to make decision about women.

Bibi Ko another female character in the novel experienced a very bad situation in her life before coming to palace to work as a cook for the male commanders. Bibi Rugul told Bibi Ko's story to Aqlima. Bibi Ko's cousin, Yama, loved her and wanted to get marry her. There was an old man named Arbab. He was a tyrannical man and had three wives at the same time. Bibi Ko was a beautiful girl when she was young. Arbab became interested in her and wanted to marry her, but Bibi Ko already loved her 
cousin, Yama. Arbab was a powerful man and had a good relationship with the government of the time. He wanted to marry Bibi Ko by force. So, the following day he killed Yama after Yama and Bibi Ko's wedding. Then, he went to Bibi Ko's house to suit her as her fourth wife. Bibi Ko gave positive response to this suit, and went as the fourth wife of Arbab. Bibi Rugul said:

He was a cruel man and had relation to the government... Arbab wanted to take Bibi Ko in his house with his ex-wives. People had said 'it is not good, stop it'. He had responded: There is no any ban from Quran and Allah's viewpoint. Prophet says so. If anyone has something to say, I divorce my first wife. She is ill and useless(ibid.).

By considering the above quote, we can find out that Homeira Qaderi intended to give the picture of a government which was cruel toward Afghan women. Men were at the top positions of the government structures, and Afghan women were only servants to men and commanders. The government of that time as one of the institutions of powerruled and controlled women. It is exactly what Louis Adrian Montrose believed that power is circulating through institutions such as family, society and the government. In addition, the government closed the female schools during Nader Shah and girls could not go to school. After a while, they re-opened schools, but they were only symbolic. No teachers, no classes and just the government was cheating women of the society.

Another novel which is interrelated to Khaled Hosseini's And the Mountains Echoed and Homeira Qaderi's Noqra, Daughter of Kabul Riveris Our Alley by Dr. Akram Usman. Mohammadi stated that Our Alley was written by Dr. Akram Usman. He was born in Herat (1316) or (1937). He studied Political Science in Kabul and University of Tehran. Usman mostly wrote his stories about social issues with a satirical view. Usman has many works in literature such as short stories and novels. His first story was published in 1339and his novel Our Alley was published in Germany (1386) (2007) and in Tehran (1388) (2009) (Mohammadi,2017).

The female characters in Our Alley have had the same fate as female characters in the previous two novels by Hosseini and Qaderi. Female characters lived under a limited life conditions of families. Here, we are going to focus briefly in the life of one of those female characters in the novel whose name was Zulikhah. She is only one pattern of other characters who beard hard conditions of life.Zulikhahwho loved Aminhad a new suitor, but she did not like the new suiter because he was old. She told the issue of suitor to her beloved, Amin. She stated: it probably it may not be important to you, but I have to tell you. You might be aware that every week of every other two weeks a suitor comes, but I accept none of them. The day before yesterday... lives in London and has three times of my age. He insisted to suit me from my father and Baba and Ache (Zulikhah's mother) usually asked my advice... I asked: Do you give me to him or his money? They answered: to both. He is $\ldots$ and experienced. He knows the values of a young woman(Usman,2013).

Here, the excerpt vividly represents that Zulikhah's parents showed agreement to satisfy her in order to accept this marriage, however, the man was old but rich. Such issue in Afghan society is quite usual. Hence, we can infer that fathers and, generally, families were the decision makers like this one in Afghan society, and they forced their daughters to accept what the family wanted. Family ruled and power lied in the hand of men which is the center of Montrose's theory of power relation.

\section{DISCUSSION}

Afghan women as half of population of Afghan society have endured endless torture and bad situation of life through the course of history. Khaled Hosseini portrayed a bright picture of Afghan women in his novel And the Mountains Echoed. However, previous critics analyzed this novel from various viewpoints such as Marxist, feministic and postcolonial feministic viewpoints, but current analysis of mentioned novel is different. The significance of this analysis of Hosseini's mentioned novel is that whatever have happened to female characters has a base in power and power structures in families, society and government. Apparently, when readers read this paper they may think of it as a feministic reading, but it is not a feministic reading. In feministic reading, everything has a gender based relation, but in new historicism everything has a power based relation. Hence, the hardships, oppressions, injustice and torture that female characters have faced in Hosseini's selected novel, Noqra, Daughter of Kabul River by Qaderi and Our Alley by Usman, has a power based relation and structures of power. It is power which is ruling and circulating through its institutions such as family, society and government in the above mentioned novels. At last,the structure of power is divided in several institutions such as family, society and government by which is circulating and ruling. 


\section{CONCLUSION}

Khaled Hosseini in his novel, And the Mountains Echoed, attempted to depict the more unpleasant picture of life condition of women in Afghanistan where power was operating everywhere through its institutions such as, family,society, and government. Since new historicism particularly Montrosean reading requires intertextual analysis of literary works, we focused on two other Afghan Novels Our Alley by Dr. Usman and Noqra, Daughter of Kabul River by Homeira Qaderi. Among many other discourse we saw that the main subject of these three novels were Afghan women. All three writers were fully aware of life condition of Afghan women. For instance, Hosseini depicted hard condition of his characters, Nila and Pari. Nila was imprisoned not to be seen by any stranger. Her father attempted to marginalize her. Hosseini also portrayed another female character, Pari, as a salable commodity that her father sold her.In Noqra, Daughter of Kabul River, we saw that Homeira Qaderi represented that her female character Noqra was rejected by her family because of pregnancy from her beloved. It was believed against to the norms and traditions of Afghan society. Bibi Ko another female character in Noqra, Daughter of Kabul River also experienced a compulsory marriage in the novel.Meanwhile, in another novelOur Alley, we saw that Dr. Usman depicted forced marriage of his female character. For example, Zulikhah, a female character loved a man, Amin, but her family forcedher to marry a suiter who was old and rich. Therefore, we can infer from all the above mentioned novels that women in Afghanistan have experienced a very sever condition of life. Because power was circulating through its different institutions such as family (father), society and the government, whatever has happened to women through institutions of power has a power-based-relations and structures of power.

\section{REFERENCES}

[1] Brannigan, J. (1998).New Historicism and Cultural Materialism, London, UK: Macmillan Education

[2] Bressler, C. (eds) (2011). An introduction to theory and practice. United States: Pearson Education, Inc

[3] Greenblatt, S.(1988). Representing the English Renaissance. California, USA: University of California Press

[4] Hosseini, K.(2013). And the Mountains Echoed, London, UK: Bloomsbury

[5] Mohammadi, M. (2017).Encyclopedia of Afghanistan Story Telling. Kabul, Afghanistan: Tak Press

[6] Prathibha, P. (2020)."There is only one, only one skill a woman like you and me needs in life... And it's this: tahamul. Endure": A Feminist Analysis of the Female Characters in Khaled Hosseini's And the Mountains Echoed and A Thousand Splendid Suns" An International
Refereed/Peer reviewed English e-Journal Vol. 5, No. 6, Apr 2020, p 39.

http://tlhjournal.com/uploads/products/4.pratibha-article.pdf

[7] Qaderi, H. (2015). Noqra, Daughter of Kabul River.Kabul, Afghanistan: Tak Press

[8] Rajkumari, C. (2019)."Representation of Love in Khaled Hossein's And the Mountains Echoed" IJELLH International Journal of English Language, Literature and HumanitiesVol.7, No. 4, April 2019, p 184.

[9] Rhudhra. (2016). Female Body as a Salable Commodity: The Psychological Dilemmas of Women Protagonists in And the Mountains Echoed. The Achievers Journal. Vol. 2, No.3, Julay-September,2016.

https://www.theachieversjournal.com/index.php/taj/article/vi ew/80/26

[10] Tantray, I\& Vats, K. (2019). Postcolonial Feministic Study of Khaled Hosseini's And the Mountain Echoed.International Journal of Science Research and Review Vol. 07, No. 06, Jun, p 901. http://www.ijsrr.co.in/images/full_pdf/1566808829_C644.p $\underline{\mathrm{df}}$

[11] Usman, Akram (2013). Our Alley. Tehran,Iran: Erfan Press

[12] Vesser, H. (eds) (1989). Introduction. The New Historicism. London: Routledge.

[13] Wolfreys, Julian (2001). Introducing Literary Theories: A Guide and Glossary. Edinburg, Germany:Edinburg University Press 